\title{
INTERNALLY GENERATED REVENUE AND INFRASTRUCTURAL DEVELOPMENT IN TARABA STATE: A TIME SERIES ANALYSIS
}

\author{
Danbeki, Alhassan \\ Federal Pay Office, Office of the Accountant General of the Federation, Jalingo \\ Email: alhassandaanbeki@gmail.com \\ Baninla, Francis \\ Federal Pay Office, Office of the Accountant General of the Federation, Jalingo \\ Email: franciswbaninla@gmail.com

\section{Bassey, Emmanuel Ude} \\ School of Basic Studies, Taraba State University, Jalingo \\ Email: emmanueludebassey@gmail.com
}

\begin{abstract}
Infrastructural development in every state is the core responsibility of every government. Funding these projects has been a challenge due to insufficient inflow to states from federal allocation and other revenue sources. This puts internally generated revenue pivotal in bridging the gap. The study examined the trend of internally generated revenue and effect on infrastructural development in Taraba state from 2011-2019. The expost facto research design, graphical representation was used with the aid of Minitab 17. The findings of the study revealed that the actual generated IGR falls below the budgeted IGR for the years covered. The actual $I G R$ stands insufficient in funding infrastructural development in the state; this calls for the urgent implementation of the suggested strategies to enhance IGR.
\end{abstract}

Keywords: IGR, Infrastructure, Development, PAYE, Direct assessment 


\section{Introduction}

The need for States to generate adequate revenue from internal sources has become a matter of extreme urgency and importance to scholars and policy makers. This is so given the everincreasing cost of running government coupled with dwindling revenue from Federal Account Allocation Committee FAAC (Mbanasor, 2014) which depend largely on revenue from crude oil (Akpo, 2009; Udoudo \& Ekpenyong, 2013; Nto, 2014). Internally generated revenue connotes revenues sourced within internal jurisdictions either at the federal level, state and local government. States reserved the legal jurisprudence to generate revenue from various sources such as taxes (PAYE, direct assessment, capital gain taxes, fines and licenses etc.).

The undermining problem is the inability of states and Taraba state specifically to generate adequate revenue to breed economic growth and development in the state. This has led to dearth of both social and economic infrastructures in Taraba state. The need for the government to provide social amenities, embark on developmental projects that would improve the living standard of her citizenry as well as meet its overhead or recurrent expenses necessitate enhanced internal revenue generation efforts. Nnanseh and Akpan (2013) opined that improvement in basic infrastructure underscores the eagerness on the part of the state to look for new sources or become more aggressive and innovative in the mode of collecting revenue from existing sources.

Lack of infrastructural amenities and the slow pace of development in Taraba state is a call for concern. Observably tied to the insufficient statutory allocation from the federal government which is not enough to cover both recurrent and capital expenditures. The problem of lack of infrastructural development in most of the states of Nigeria is not a new one. Taraba state lacks infrastructural development probably because what comes from the federation Account as statutory share is not enough to cover both personnel and other related costs.

Taraba state is a state in Northern Nigeria, named after the Taraba River. Bounded in the west by Nasarawa state and Benue state, northwest by Plateau state, north by Bauchi state and Gombe, northeast by Adamawa state, and south by Nord-Ouest province, claimed by both Ambazonia and Cameroun. The study focused on examining the trend of internally generated revenue in Taraba state for the past nine years, evaluates the impact on infrastructural development and suggests strategies to enhance revenue generation in the state.

\section{Endogenous Growth Theory}

Propounded by Romer (1994), endogenous growth theory holds that economic growth is anchored on investment in human capital, innovation and knowledge management. The theory accommodates government strategic policies that spur economic growth. Omodero, Ekwe and Ihendinihu (2018) postulated that homogeneity in IGR sources and opportunities is absent in both states and local government areas, but the government at the center gives states the privilege to harness all available resources within the ambit of the law and constitution of the country. Encouraging the legitimate exploitation of means of enhancing revenue generation. Enshrined in the 1999 constitution of the Federal Republic of Nigeria, is the autonomy for state and local government to internally generate revenue for the development of the state and local government areas. The constitution permits the collection of personal income tax, capital gains tax and stamps duties which are federal taxes to be collected at the state level where a law of the 
National Assembly has been enacted. More also, beyond the provision in the constitution which specifics charges that can be charged by the local governments, the constitution also provides that the State House of Assembly can enact such laws as may be necessary and are not in conflict with the constitution for the peace, order and good government of the state. These general provisions give scope to the state to enact laws (for both state and local governments) that would ensure good governance beyond those taxes and revenue sources that are enshrined in the constitution (Okeke, Mba \& Eme, 2017).

\section{Methodology}

The study adopted ex-post facto research design which provides empirical solution to research problems by using already existing data. The secondary data were collected from Taraba State Ministry of Finance 2011 to 2019. The data were collected on internally generated revenue (IGR) proxied as PAYE, Direct assessment and fines and licenses and on the predictor variables which were Infrastructural development proxied by annual expenditure on Water infrastructure, Road infrastructure, Electricity infrastructure, Educational infrastructure. The data have been tabulated and statistically analyzed using time series graphical visualization with the aid of Minitab 17.

\section{Model specification}

$\mathrm{ID}=\mathrm{f}(\mathrm{IGR})$

This is mathematically specified as follows:

$\mathrm{ID}=\alpha_{\mathrm{o}}+\alpha 1 \mathrm{IGR}+\mathrm{e}$

The model is enlarged thus:

$\mathrm{ID}=\beta \mathrm{o}+\beta_{1} \mathrm{PAYE}+\beta_{2} \mathrm{DA}+\beta_{3} \mathrm{FL}$

Where $\beta 1, \beta 2$ and $\beta 3$ represents $\alpha 1$ 


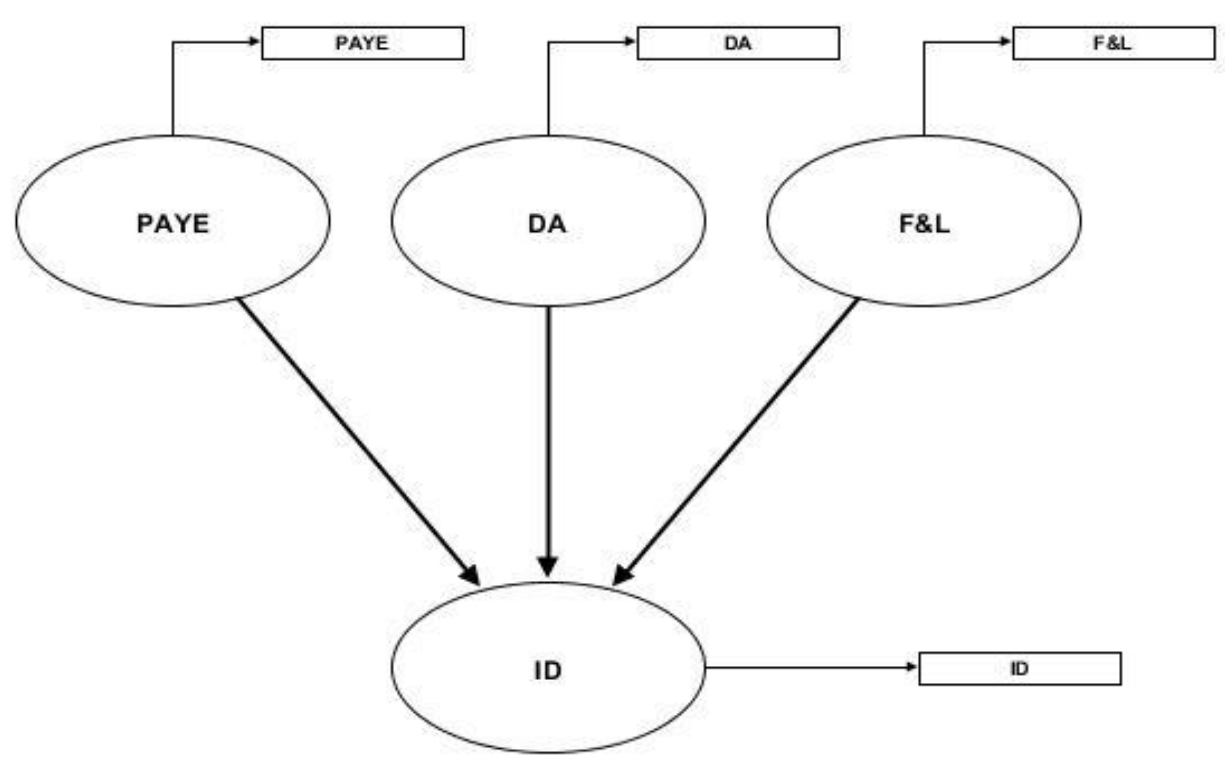

Figure 1: Conceptual framework

\section{Data Analysis:}

\section{Data Visualization}

\section{Taraba State Government Revenue and Expenditure Pattern}

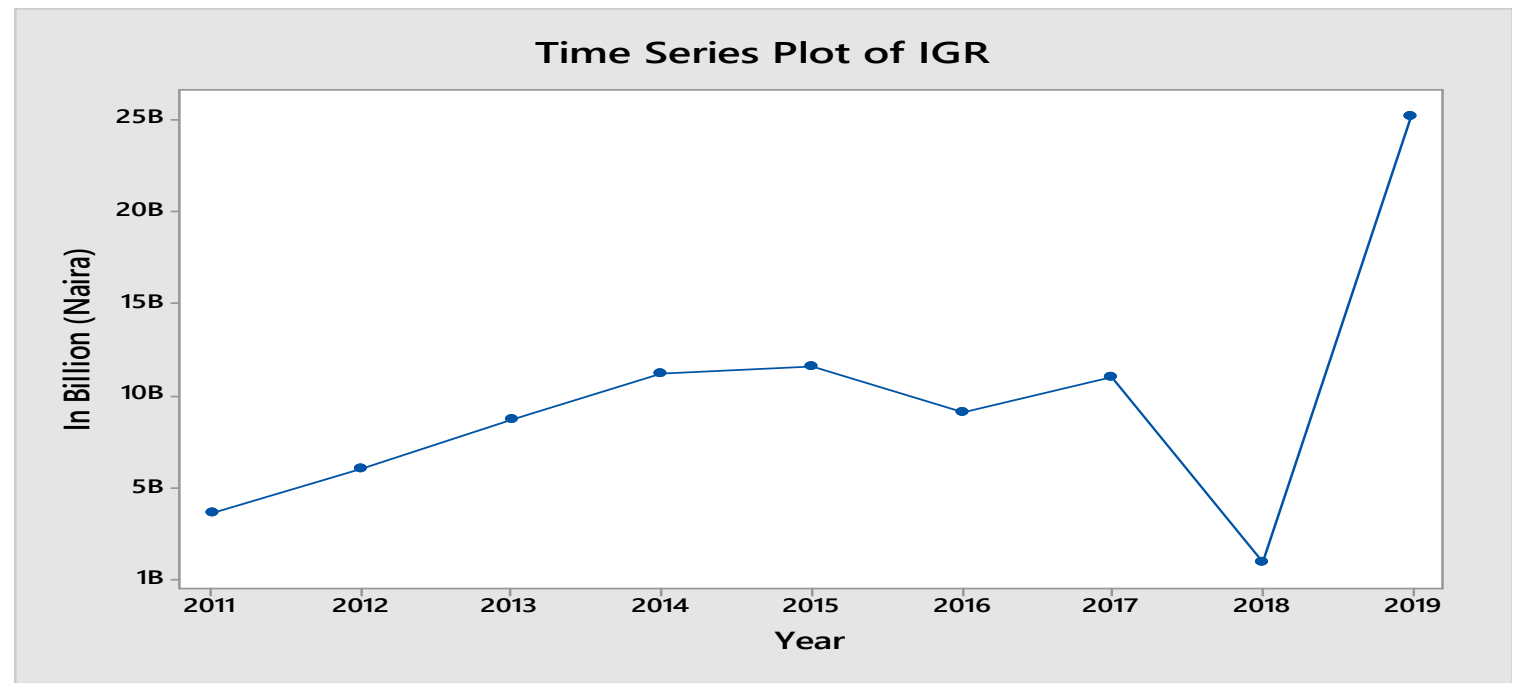

Figure 2: Revenue plot

The time series plot above indicates the movement of internally generated revenue in Taraba from 2011 to 2019. The IGR showed a consistent rise from 2011 to 2015 with a drop in 2016, picking up in 2017 and an adverse drop in 2018. 2019 showed a favourable increase in IGR. 


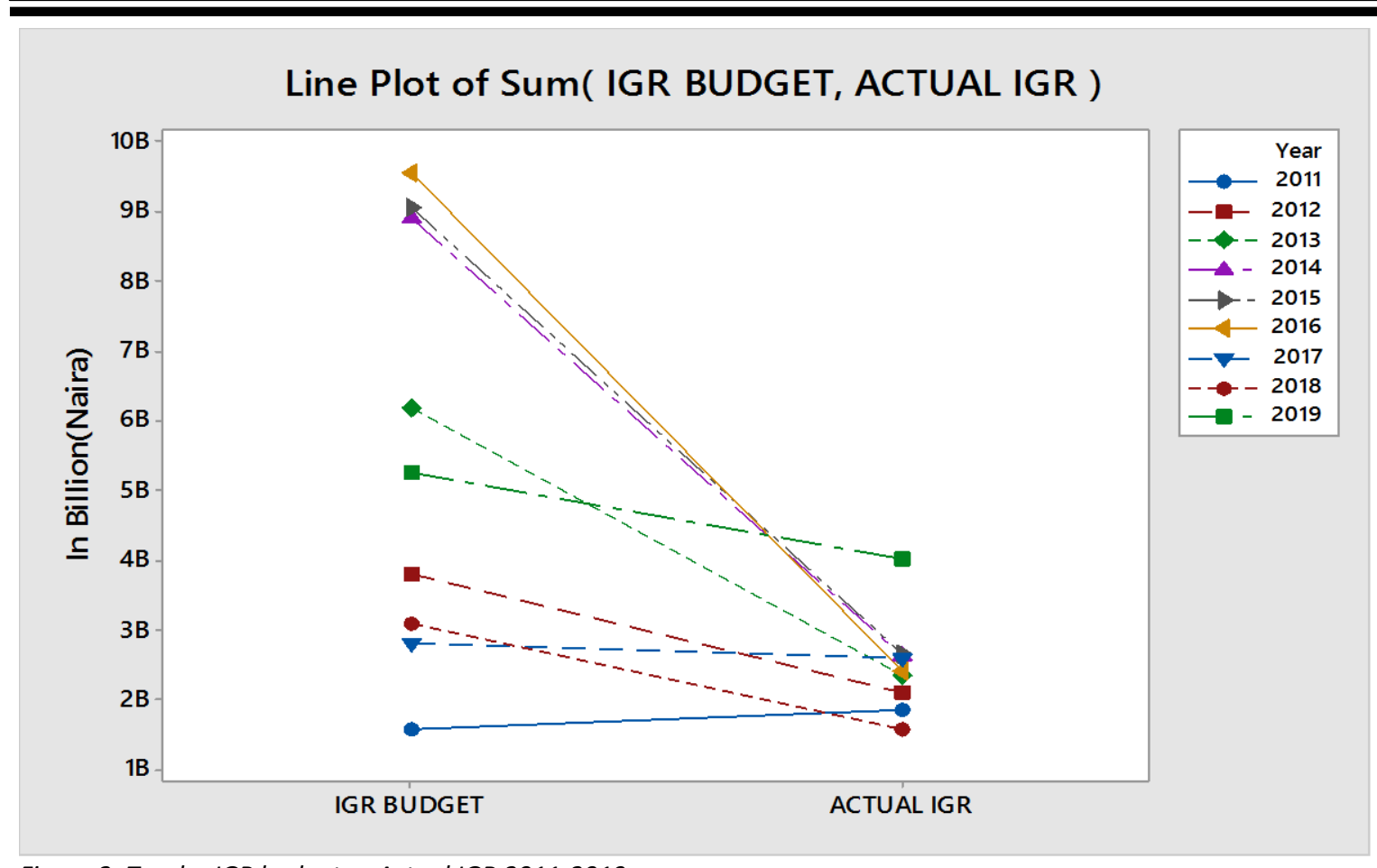

Figure 3: Taraba IGR budget vs Actual IGR 2011-2019

The plot above shows the budgeted IGR and the actual IGR for the years 2011-2019. The line movement indicates that the actual internally generated revenue falls far below the projected.

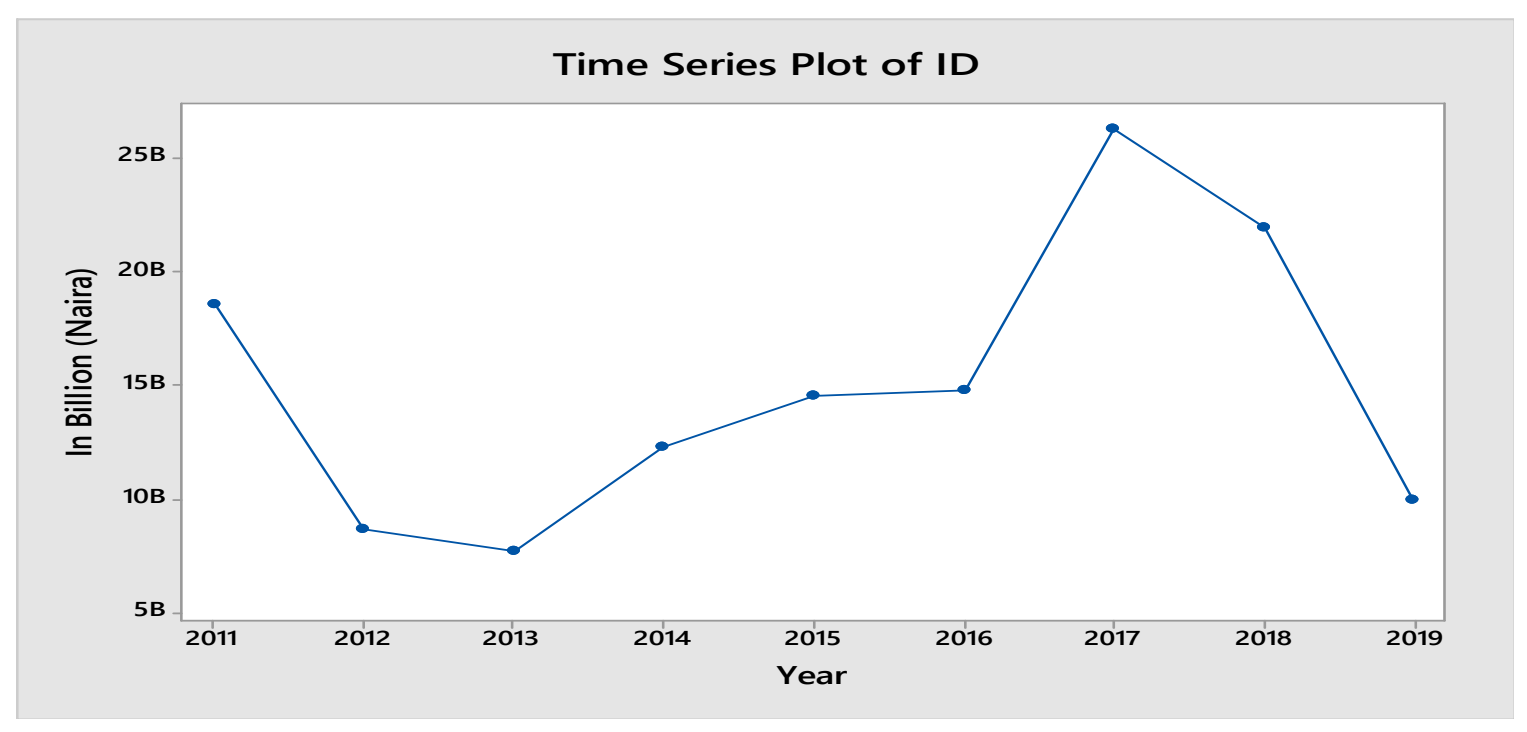

Figure 4: Infrastructural development plot

The time series plot above indicates the financial expenditure of Taraba state on infrastructural development from 2011 to 2019. This expenditure captures water, electricity, roads, education 
and health in terms of buildings and renovations. 2013 showed the lowest while 2017 showed the highest.

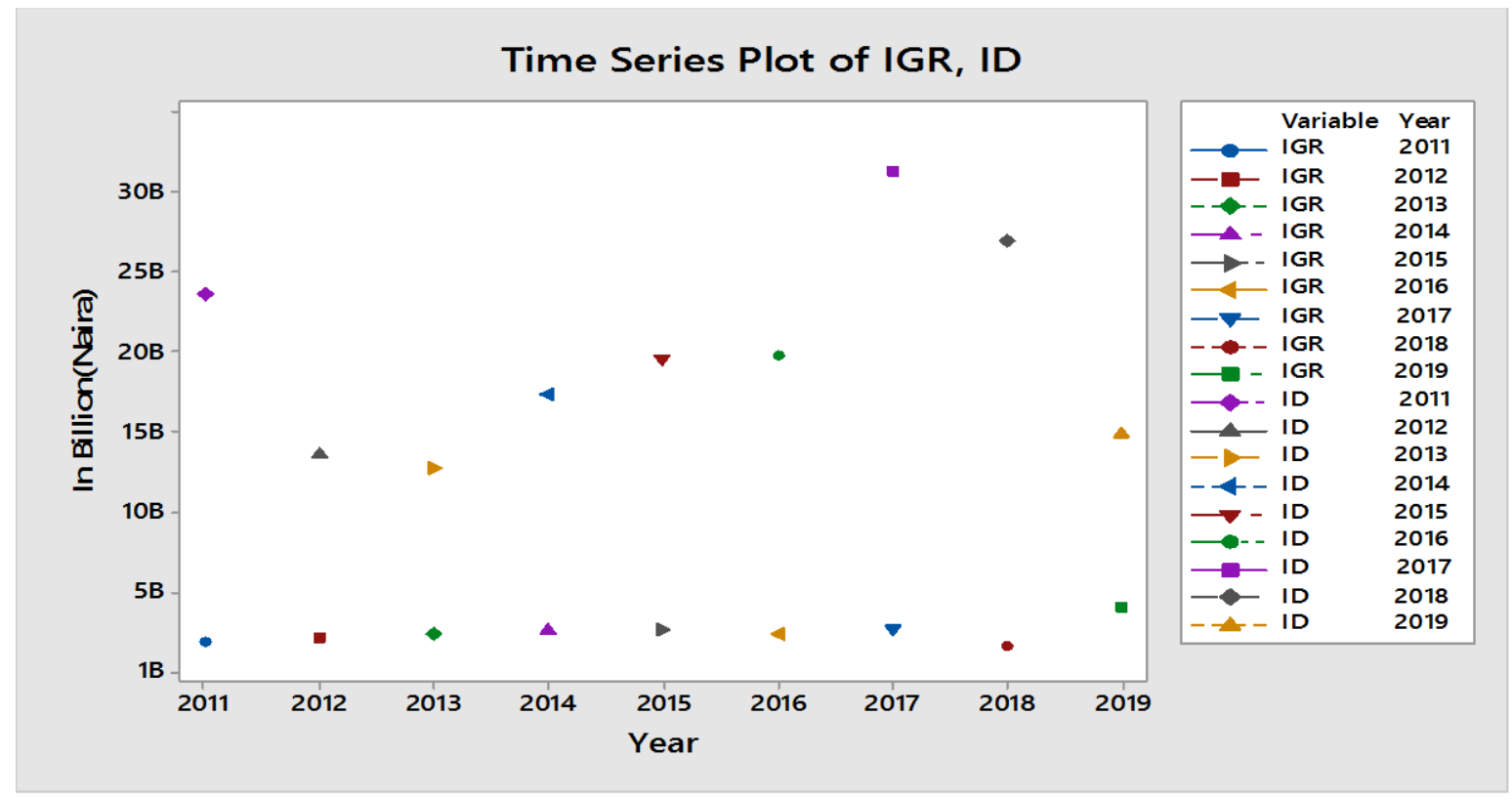

Figure 5: Actual IGR and ID expenditure

The times series plot of revenue against infrastructural development in the state within the time covered showed that the IGR generated from 2011 to 2019 was insufficient to fund infrastructural facilities in the state. This explains that more than $50 \%$ of the ID expenditure was funded from federal allocation and other revenue sources.

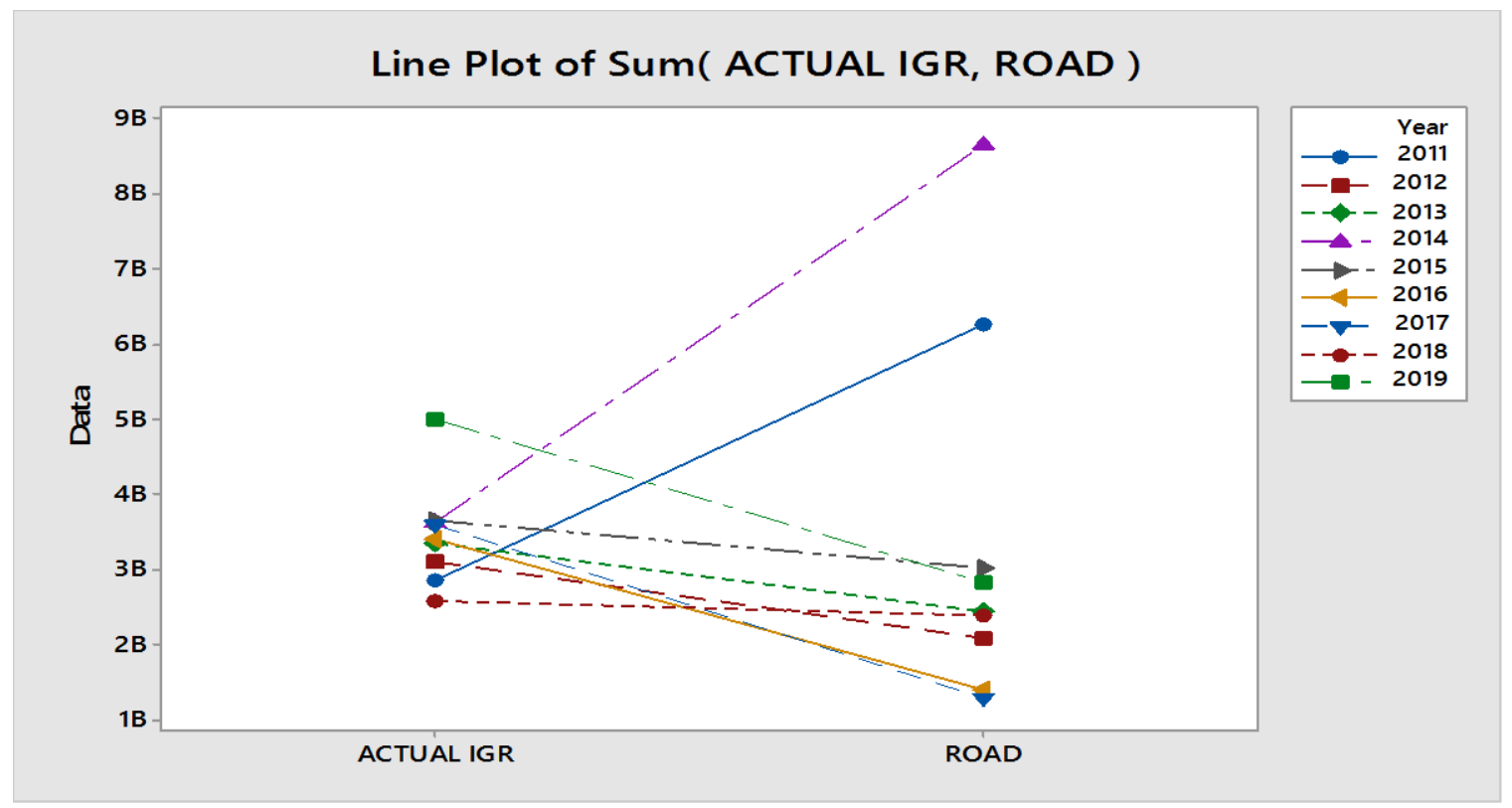

Figure 6: Actual IGR vs Road Expenditure 
International Journal of Advanced Academic Research (Social and Management Sciences) | ISSN: 2488-9849 Vol. 6, Issue 12 (December, 2020) | www.ijaar.org

Journal DOI: 10.46654/ij.24889849

Article DOI: 10.46654/ij.24889849.s61217

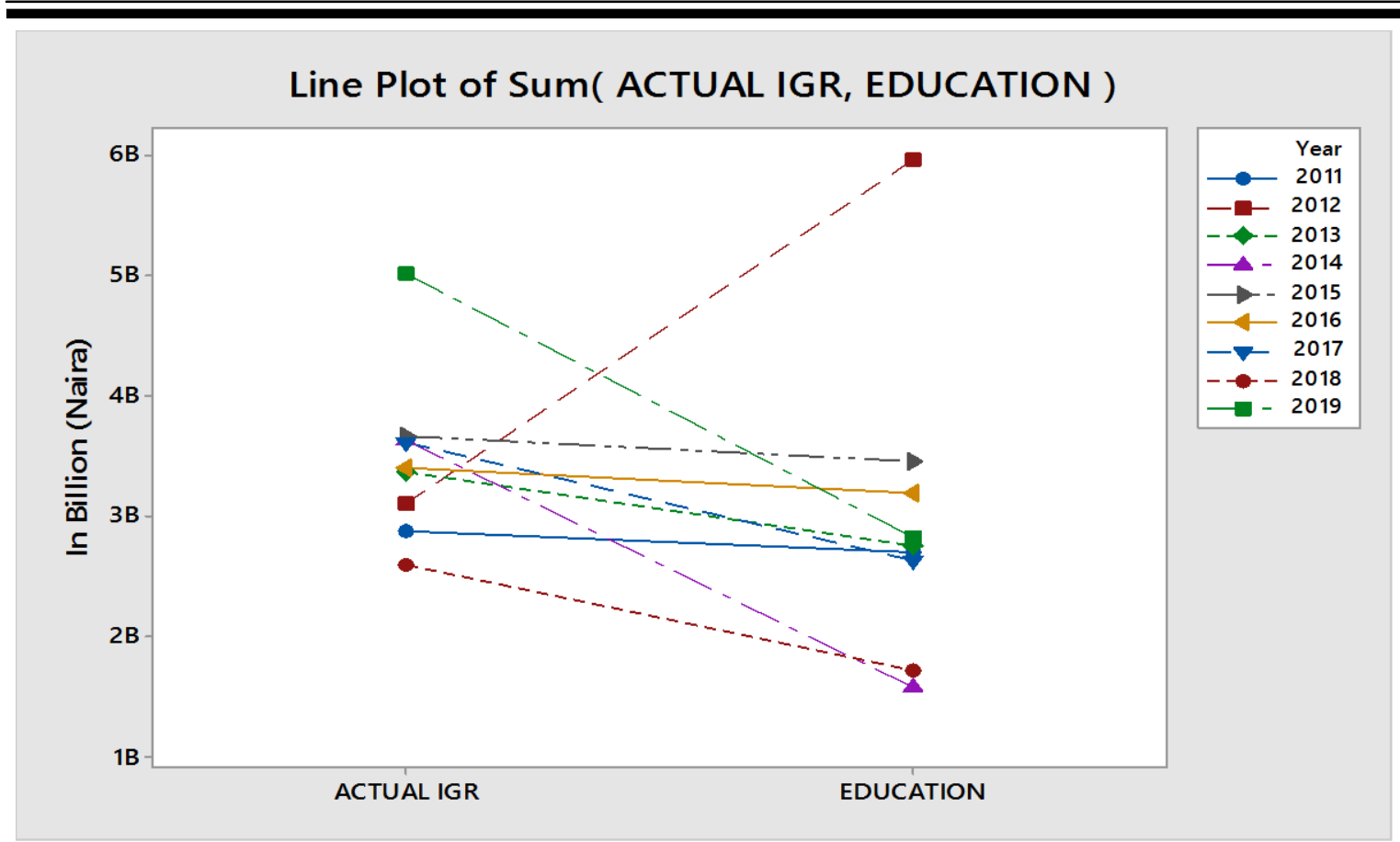

Figure 7: Actual IGR vs Education expenditure

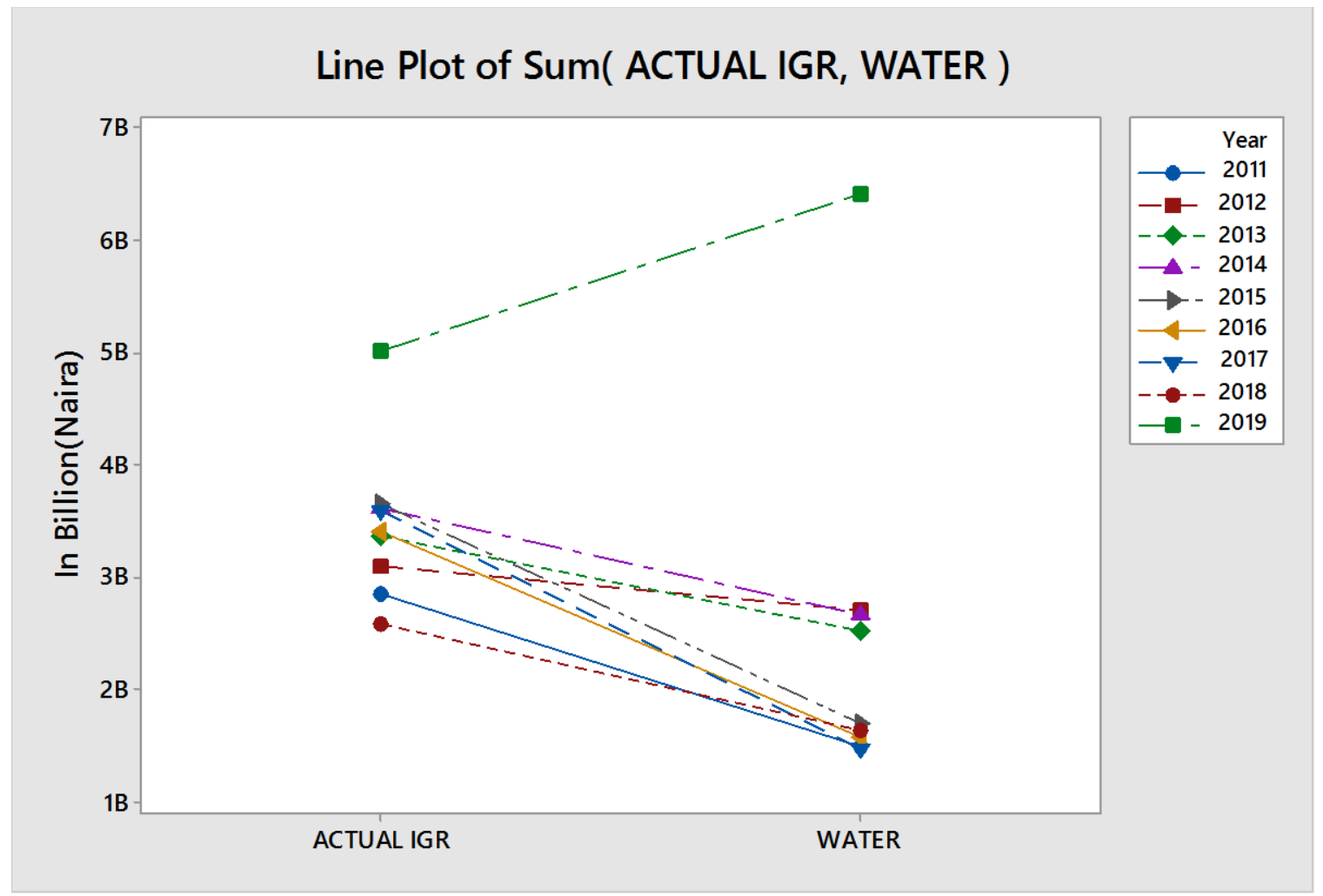

Figure 8: Actual IGR vs Water expenditure 
Journal DOI: 10.46654/ij.24889849

\section{Strategies for Revenue Enhancement in Taraba State}

Strategies are eminent in widening the scope of revenue generation in the state. In order to achieve the targeted IGR and to provide more sufficient developmental services, the government must look into human capital and business investment to boost revenue. Mitigating present revenue collection challenges and eliminating corrupt practices in the collection and remission process stand paramount. Hofer and Schedal (1978) suggested the following strategies:

- Introduction of additional sources of revenue.

- $\quad$ Providing an incentive for extra efforts of the revenue generation staffs.

- $\quad$ Periodic raiding by officer of the revenue generation.

- $\quad$ Efficient and effective collection of existing taxes.

- $\quad$ Public enlightenment and campaign that will educate the tax payer on the importance of prompt payment.

There is need for self-sufficiency in terms of revenue in Taraba state. It is hoped that the pressure to diversify and focus less on the center will compel states to explore alternatives for improving their revenue base (Balogun, 2015). In order to enhance internal revenue generation in Taraba state, Okeke et al. (2017) strategies could be implemented to improve on IGR. The three (3) strategies identified are centered on taxes collected by the state Board of Internal Revenue and nontax originating from other revenue points. Firstly, expansion of tax base is pivotal which entails crystalizing and statistically picking out those not paying tax at present. This will also require the implementation of new taxes or further increase in tax rate. Achieving an enhanced IGR from the first strategy incorporates a system were the TBIR generates and holds a data base comprehensive enough to provide inherent information on revenue estimation based on empirical data not guess approximation. Secondly, there is need to improve tax payer's compliance, through effective audit, penalties and enforcement of unpaid debts. Lastly, developing a workable non tax revenue sources (See Okeke et al., 2017).

\section{Conclusion/Recommendation}

The survival of states and speedy rapid development is unarguably anchored on their ability to generate sufficient revenue internally to fund projects and settle recurrent expenditures as and when due. The challenge has always been insufficient allocation from the federation account to fund state developmental projects, this brings the states to the planning table to strategically device means to generate revenue enough to fund its developmental plan. The potentials to grow and develop rapidly are hidden within the individual states left to be harnessed. The states need to engage information technology in expanding tax base and creating more non tax revenue avenues in the new normal. The study thus recommends that there is an urgent need to expand the revenue base of the state in order to generate more revenues to have effect on the state government annual budget. 


\section{References}

Akpo, U. (2009). The people as government: Imperatives of tax payment. Being a paper presented at the 1st Akwa-Ibom State revenue summit. April 6 and 7, 2009, Uyo.

Hofer, C., \& Schendel, D. (1978). Strategy Formulation: Analytical Concepts. St Paul West Publishing Company, MN.

Mbanasor, J.A. (2014). Poor increasing IGR in Abia State. Paper presented at the first Abia revenue summit, 10th July, 2014, at Michael Okpara Auditorium, Umuahia.

Nnanseh, M., \&Akpan, S. S. (2013). Internally Generated Revenue (IGR) and infrastructural development in AkwaIbom state. European Journal of Business and Management, 5(31), 165-172.

Nto, P.O.O. (2014). New face of Abia tax policy. An address presented at the Maiden Abia revenue summit on July 10, 2014, Umuahia.

Okeke, M. I., Mba, C \&Eme, O. I. (2017). Enhancing Internally Generated Revenue: Issues, Strategies, Foresight \& Insights. Specialty Journal of Humanities and Cultural Science, 2 (1): $1-22$

Omodero, O. C., Ekwe, C. M., \&Ihendinihu, J. (2018). Impact of internally generated revenue on economic development in Nigeria. Accounting and Finance Research, 7(2), 103-114.

Roma, P. M. (1994). The origins of Endogenous Growth. The Journal of Economic Perspectives, 8(1), 3-22. JSTOR. https://doi.org/10.1257/jep.8.1.3

Udoudo, P.U. \&Ekpeyong, E.J. (2013). Modelling internally generated revenue (IGR) of local government in Nigeria.Mathematical Theory and Modelling, 3(14). 